\title{
Inquiry Model Of Panorama Map In Writing Learning Integrated With Scouts
}

\author{
Diyamon Prasandha ${ }^{1}$ and Wagiran ${ }^{2}$ \\ \{1diyamonprasandha@mail.unnes.ac.id, ${ }^{2}$ wagiransuwito@mail.unnes.ac.id\} \\ ${ }^{12}$ Indoesian Language and Literature Education, Universitas Negeri Semarang
}

\begin{abstract}
Writing abilities of students in various levels of education are generally still not appropriate with the expectation. The basic problem is due to time limitation in writing learning. These problems can occur in the learning outside of the classroom. Time as one of the obstacles in the learning process can be overcome by combining learning with extracurricular activities, namely scouts. It is necessary to develop an adequate inquiry model for the implementation of the learning activities, namely the inquiry model of panorama map. The inquiry model panorama map integrated with scout activities has syntactic, including (1) orientation phase, (2) ideal phase, (3) adjustment, (4) description phase, (5) assessment, and (6) generalization phase.
\end{abstract}

Keywords: syntactic, inquiry model, writing

\section{Introduction}

The low of student literacy culture is proved by the lack of reading and writing culture. Students can read and write but many of them do not read and write. Compared with literacy in western, literacy in Indonesia is still lower. Literacy is defined as the ability of students in literacy discourse. The initial skills emphasize to the development of reading and writing competencies. The ability in literacy is an integrated form the ability to listen, speak, read, write and think critically. In its development, literacy is an effort to improve language and literature skills related to the success in achieving the competencies that have set in the curriculumz [1].

Student writing literacy competency standardized in the curriculum is also low. Students have not been able to produce writing in accordance with the demands in the curriculum used. Based on the various types of writing, descriptive text requires accuracy, cohesion, wrinkling, and involves the senses. Description text is one form of discourse that seeks to present an object or thing in such a way that the object seems to be in front of the reader's head, as if the reader saw it [2]. Paragraph description limitation as a writing which as a purpose to provide details or details about the object so that it gives the reader imagination [3]. Writing learning, especially writing descriptive text, is a skill that aims to propose an object or something that the object seems to be in front of the reader's head.

To overcome the difficulties faced by students in writing, an appropriate learning model is needed, one of them is the inquiry model. The inquiry model proved to be more effective than the lecture model [4]. The inquiry model is not only develops intellectual abilities but all 
potentials exist, including emotional development and inquiry skills is a process that starts from formulating problems, formulating hypotheses, collecting data, and making conclusions. Inquiry model is a model that prepares students in a situation to conduct their own experiments widely to see what is happening, interest to do something, ask questions, and find the answers themselves, and connect one findings with other findings, compare what was found with other students. Every opportunity to let students work with their hands is a good way to use inquiry-based learning that there was significant effect of inquiry based learning technique [5]. Hand skills can be used in all subjects. One example like this might giving students (both individually and in groups) foreign objects. Let them see and hold objects and speculate how they can be used.

\section{Research Method}

Research and development approach was used in this study with the development procedure including data collection and analysis, initial product development, validation, product testing, revision, and final product. The data were gathered by interviews, observations, and survey. The data then were analyzed using qualitative descriptive method. Appropriate field study methodes reflect the purpose and times resources available. Suggestions have been given and newer participatory methodes, techniques and tools presented to fasilitate studies using methodological pluralism, method combinatios, flexibilty and iterative reseach prosess [6].

\section{Results And Discussion}

Characteristics of Panorama Map Inquiry Model of Descriptive Writing Learning Integrated in Scouting Activities

\subsection{Syntactic}

The syntactic (sequence pattern) of a learning model is a pattern that illustrates the sequence of the flow of the overall stages which are generally accompanied by a series of learning activities [7]. Syntactic (sequence pattern) in the panorama inquiry model in writing descriptive text integrated with scout activities, namely (1) apperception of activities, including the introduction of places as locations of activities and providing direction for the implementation of activities for students. At the apperception stage there is an orientation phase. In the orientation phase, the scout coach tells the introduction of the place as the location of the activity, conveys the purpose of the activity, steps of implementation and benefits of the activity; (2) exploration, there is an ideal phase, this stage students explore information and material writing activities descriptive text and write an ideal picture of the location of the panorama; (3) elaboration, at this stage there is an adjustment phase and a description phase, students find panorama map objects and identify and describe them into descriptive text; (4) confirmation, at this stage there is an assessment phase, given feedback to students related to learning that has just been experienced with a panoramic inquiry model integrated with scout activities and assessment of students' work; (5) reflection, is the stage of formulating the conclusions and flashback concepts of the panoramic inquiry model in writing descriptive essays that are integrated with the scouting activities (generalization stage). 


\subsection{Social System}

The social system is the provisions and rules that applied in the panorama inquiry model in writing descriptive text that is integrated with scout activities. A comfortable atmosphere is important in the inquiry model. The role of the coach is trying to create a comfortable atmosphere and become a facilitator who prepares scout activities in writing descriptive text. The coach designs the activity and prepares the activity and removes the supporting tools for the activity process. The students are guided by the teacher and the scout couch to investigate in drawing a panorama map until they can describe it into a descriptive text and evaluate the students' work. Students as the center of activities are required to perform all stages of the descriptive writing learning with a panorama inquiry model integrated in the scout activities, drawing a panoramic map and describing it into a descriptive text on the worksheet that has been provided.

\subsection{Principles of Management / Reaction}

The principle of reaction is a pattern of activities that illustrates how the coach should look and treat students, including how the coach should respond to them. The principle of reaction includes: (1) convey the objectives of the activity to be carried out clearly so that students can understand; (2) guide students during the panorama map drawing activity; (3) guide and encourage students in writing the framework up to writing a descriptive text based on a panorama map that has been made; (4) provide examples of panorama maps, frameworks and descriptive text.

\subsection{Support System}

The support system is all media, materials, and tools that support the implementation of the panorama map inquiry model in descriptive writing. Without being supported by the tools needed, the implementation of learning models outside of the class will not run optimally. The tools needed are pencil or pen, ruler, eraser, compass, and student worksheets.

\subsection{Instructional and Accompaniment Impacts}

Instructional impact is a learning achievement that is achieved directly by directing students to the expected goals. While the accompaniment impact is other learning achievement as a result of participating in the activities carried out. The instructional impact of the panorama map inquiry model in writing descriptive text integrated with scout activities is (1) being able to write descriptive text, (2) care for the environment, (3) passion and creative. 


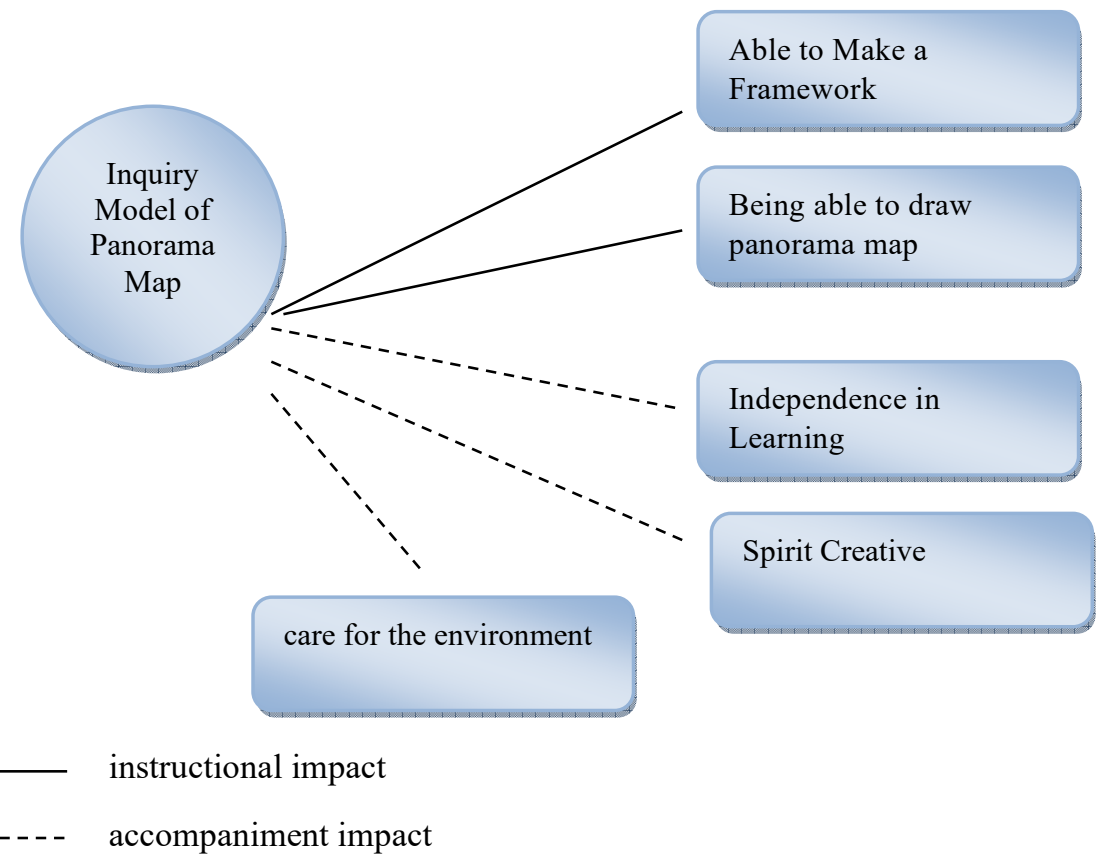

Media outside of the classroom is very helpful for students to be able to describe what will be written. Time as one of the obstacles in the learning process in classroom can be overcome by diverting the learning process outside the classroom or by integrating learning with extracurricular activities in school. Scouting can be used as a way to develop the potential of young generation of the nation who are skilled, authoritative, care for the environment. on Scouting is the process of forming the personality, life skills, and noble character of scouts through the appreciation and practice of scouting values [8].

The limitation of time allocation in the learning process in the classroom caused the existence of activities as solutions that facilitate students in writing learning. Scouting was chosen as an activity that facilitates students learning because the activity is part of an extracurricular education process that aims to encourage students self-development and talent in obtaining life skills. The nature and the form of scouting activities are positive activities that are fun. Students are lead and guided by teachers and scout coaches. This activity is held in the outside of the classroom by using basic principles and scouting methods. The material taught during scout training is very diverse, one of them is drawing a panorama map. Panorama map is a picture of natural scenes drawn by using shading. The purpose of making this panorama map is to describe the state of an area with a certain range or point of view. Students are invited to play and learn through one of the panorama map activities. After students play to draw a panorama map, students describe what they see. Time limitation, the lack of time in learning to write descriptive text and less motivation make scouts as a way of learning descriptive of students. The concept of the outdoors relating to scout activities is integrated in descriptive writing material. By combining the concept of nature, the process of collaborating with Indonesian material subject with a panorama map of the surrounding natural environment. There are several important reasons that become reasons the design of a descriptive writing activity model that is integrated with scouting activities. The time limitation of the teacher in teaching Indonesian language generally and in writing descriptive 
particularly. The practice of writing various kinds of texts were conducted at home because the teacher's face-to-face time with students is only two hours for each week.

Students are more free to study outside the classroom. Students can observe objects directly without have to imagine the classroom. Through this model, it is expected to increase students' enthusiasm in learning. Students' enthusiasm for scouting activities can be seen in the level of attendance of scout training every week, especially scouting activities are mandatory extracurricular activities for class X students. It can encourage them to learn better because the inquiry model of panorama maps is carried out during routine scout exercises. Drawing panorama maps is not difficult thing. Drawing a panorama map is easy for scout enforcers. There is also scout's General Skills Requirement in drawing a panorama map scouts enforcement. So, all vocational students are required to be able to draw a panorama map. It can facilitate the implementation of the panorama map inquiry model because students know the panorama map. The relevance of this condition, it is very urgent to try to guide Indonesian learning models, namely the inquiry model of a panorama map of learning to write descriptive text integrated in scouting activities for students.

If traced actually very rarely research that discusses integrating learning models with scouts. But there are a number of journals that talk about integrating learning. First A generic model for guiding the integration of ICT into teaching and learning. Innov Educ Teach Int [9]. The article integrates learning by using information and communication technology and is very effective. Second Inspiration and intellect: Significant learning in musical forms and analysis.is to integrate learning with learning experiences [10]. Something similar also exists in this research that is correlating with experience through nature scouting in scouts. Research using the inquiry model has also been carried out by Sinegar. With the title Inquiry learning strategy to improve mathematics achievement of junior high schooL [11]. The results obtained using the inquiry model the results are increasing. Other research that is still about the use of inquiry is by Hermanto et al with the title [12]. The results of this study prove an increase in the ability to write text descriptions of students after learning by using the inquiry learning model as a whole there was a significant increase both in terms of the results of the assessment of learning planning (RPP), and implementation. Similar to this development research, the same is applying inquiry, but it is only implemented by integrating learning with scouting [13].

\section{Conclusion}

The phases of activities in the development of a panorama inquiry model in writing descriptive text integrated with scouting activities included 6 phases namely, (1) Orientation phase, (2) ideal phase, (3) adjustment phase, (4) description phase, (5) assessment phase and (6) generalization phase. These phases are intended to help students in descriptive writing while aligning and increasing the sensitivity of life with the natural surroundings. In general, the characteristics of this model consist of syntactic, social system, reaction system, instructional impact and accompaniment which combines the learning of descriptive writing with the inquiry model on scouting activities. 


\section{References}

[1] M. Doyin, "Selamat datang, Hoax!," in Prosiding Wacana Bahasa, Sastra, dan Pengajarannya, 2017.

[2] G. Keraf, Komposisi. Ikrar Mandiri Abadi Jakarta, 2006.

[3] A. Semi, Menulsi Efektif. Angkasa Raya Padang, 2003.

[4] S. Annan, ... F. A.-... of E., and undefined 2019, "Assessment of the Inquiry Teaching Method on Academic Achievements of Students in Biology Education at Mawuko Girls School, Ho, Ghana," Article.Scieducationalresearch.Com, vol. 7, no. 3, pp. 219-223, 2019.

[5] Y. Irawan and D. Sofyan, "The Effect Of Using Inquiry Based Learning Strategy," vol. 3, no. 2, pp. 59-79, 2004.

[6] B. Milkkelsen, Methods for Development Work and Research: A New Guide for Practitioners. Sage Publication India Pvt Ltd, 2005.

[7] Triyanto, Model-model Pembelajaran Inovatif Berorientasi Konstruktivistik. Prestasi Pustaka Jakarta, 2007.

[8] "Undang-Undang No 12 Tahun 2010 tentang Gerakan Pramuka," 2010.

[9] Q. Wang, "A generic model for guiding the integration of ICT into teaching and learning," Innov. Educ. Teach. Int., 2008.

[10] B. C. Kelley, "Inspiration and intellect: Significant learning in musical forms and analysis," New Dir. Teach. Learn., 2009.

[11] E. Siregar and S. R. Sirega, "Inquiry learning strategy to improve mathematics achievement of junior high school," J. Phys. Conf. Ser., vol. 1188, no. 1, 2019.

[12] Hermanto and Sidi; Farida Ariyani; Muhammad Fuad, "J-Simbol (Bahasa, Sastra, dan Pembelajarannya) Mei 2019,” 2019.

[13] K. Saddhono, I. K. Sudarsana, and A. Iskandar, "Implementation of Indonesian Language The learning Based on Information and Communication Technology in Improving Senior High School Students' Achievement in Surakarta," in Journal of Physics: Conference Series, 2019, vol. 1254 , no. 1, p. 12059. 